\title{
Protection of Intellectual Property Rights in Ukraine in the Light of European Integration Processes
}

\author{
Andrii Neugodnikov ${ }^{1}$, Tetiana Barsukova ${ }^{2} \&$ Roman Kharytonov $^{3}$ \\ ${ }^{1}$ Associate Professor of the Department of Administrative and Financial Law, Head of the Faculty of International \\ Legal Relations, National University “Odessa Law Academy”, Odesa, Ukraine \\ ${ }^{2}$ Senior Lecturer of the Department of Physical Education, National University "Odessa Law Academy", Odessa, \\ Ukraine \\ ${ }^{3}$ Associate Professor of the Department of International and European Law, National University "Odessa Law \\ Academy", Odessa, Ukraine \\ Correspondence: Andrii Neugodnikov, National University "Odesa Law Academy”, Odesa, Ukraine. E-mail: \\ neuandr79@gmail.com
}

Received: June 19, 2020

doi:10.5539/jpl.v13n3p203
Accepted: August 13, $2020 \quad$ Online Published: August 30, 2020

URL: https://doi.org/10.5539/jpl.v13n3p203

\begin{abstract}
The article provides an assessment of the state of legislation of Ukraine on the protection of intellectual property at the present stage. The most important problematic aspects and prospects of improving the legal regulation of intellectual property protection on the way to European integration are described in detail.

The experience of foreign countries in ensuring the protection of intellectual property is analyzed. Particular attention is paid to the features of computer program protection, which is especially relevant nowadays. Features of the use of license agreements by the owner of computer programs, namely BSD License, Apache License, GNU General Public License, GNU Lesser General Public License, were analyzed.

The conclusion is drawn that a system of continuous analysis of decisions made by European countries in the field of intellectual property law, as well as on issues related to general state policy on the administration of intellectual property, in order to implement developed approaches to legislation and law enforcement practice, could improve the protection of intellectual property rights in Ukraine.
\end{abstract}

Keywords: intellectual property, protection, European integration, license, World Intellectual Property Organization, World Trade Organization

\section{Introduction}

Property protection issues have always been relevant. From the middle of the XX century, special attention is paid to property in the field of intellectual activity, such as: musical works, drawings, ideas for the design of mechanisms, algorithms, inventions and more. Globalization leads to mainstreaming of national issues in the light of international processes. Since new discoveries are being made almost daily, there is an urgent need to regulate this area of relations, so that everyone can feel free to create, use, dispose of, protect intellectual property rights. Nowadays, issues related to the protection of intellectual property in the world have come to the fore. Due to the comprehensive intellectualization of the modern world economy, they are becoming a problem related to economic security and require strategic approaches to their solution.

In recent years, Ukraine has significantly intensified the process of joining the global structures governing intellectual property, and is already a party to more than ten international conventions and treaties in this area. The process of joining the World Trade Organization (hereinafter - WTO) has also been completed and participation in the Agreement on Trade-Related Aspects of Intellectual Property Rights has been secured. The process of acceding to a number of international conventions and treaties continues.

Currently, Ukrainian legislation does not fully regulate the issue of intellectual property protection, because the laws do not provide for this mechanism, the practice of termination is not effective. There is also no loss-friendly mechanism for calculating losses, which is why people often do not receive adequate compensation. Today, Ukraine is reviewing its own legislation for compliance with international democratic, legal standards. Therefore, 
it is important to study the existing vector of development of intellectual property law, to analyze Ukrainian realities and proposals for improvement, as well as practices to ensure the intellectual property rights.

The purpose of this work is to describe and develop a holistic and complete view of the nature, types, means of protection of intellectual property, compiled on the basis of generalization, analysis and systematization of existing researchi in this field of knowledge. The purpose is based on the further development and characterization of theoretical provisions, development of methodical recommendations concerning protection of intellectual property and efficiency of its use in the conditions of European integration processes.

\section{Material Studied, Area Descriptions, Methods}

Issues of protection of intellectual property rights have not yet taken their rightful place in the plans of research work of scientific and educational institutions. Nevertheless, there is a lack of special researches on the protection of intellectual property rights in Ukraine so far, although these issues, in one way or another, are highly discussable. However, published scientific articles on the protection of intellectual property rights do not create a holistic view of the state of protection of intellectual property rights. At the same time, even at this level, the principles of civil law protection of intellectual property rights under the new Civil Code of Ukraine have not been properly researched.

At the same time, the issue of protection of intellectual property rights cannot be considered only as scientific and theoretical. First of all, it is important for law enforcement practice, lawmaking. Controversial issues of protection of intellectual property have general legal significance. All these circumstances determine the relevance of this study.

The methodological basis of the research is a system of interrelated general scientific and special methods of scientific research, the application of which ensures the reliability of knowledge and the solution of the set purpose and objectives.

The research was carried out on the basis of formal-logical, comparative-legal, historical methods and purely legal techniques.

Using the historical method, the evolution of the legislator's approaches on insuring the protection of intellectual property rights has been analyzed. The formal-logical method has been used to analyze the provisions of the legal acts in the field of intellectual property rights protection.

The very important for the research method was the comparative legal method. It was used to make a comparison of the provisions of the laws of Ukraine and other countries as well as to identify, which international legal acts have influenced the national Ukrainian legislation in the field of intellectual property rights protection.

The current situation and needs in the field of intellectual property rights protection were revealed using dogmatic and legal methods.

\section{Results and Discussion}

\subsection{International Experience in Legal Protection of Certain Objects of Intellectual Property Rights}

The problem of copyright protection in the most pronounced form is manifested in the last decade in the Internet, primarily due to the simplicity and speed of posting information on the World Wide Web, the lack of mandatory authorization for such actions, openness and accessibility of electronic resources to unlimited circle of people. Thus, it is necessary to analyze the approaches developed in world practice to the protection of intellectual property rights infringed on the Internet, regarding computer programs and public licenses of free software.

The process of creating a legislative basis for the legal regulation of intellectual property relations in Ukraine has come a long and difficult way, which is continuing. Legislation in this area began to take shape in 1993 with the adoption of the first special laws on the protection of rights to certain intellectual property. The adoption of these acts was at that time rather advanced, modeling value, because it took place in conditions when the real economic relations of a market nature in the field of use of the results of intellectual work were just emerging ${ }^{1}$.

Special laws are mainly focused on regulating the procedure for acquiring property rights to intellectual property (by obtaining a patent, certificate). Instead, the peculiarities of the realization of property rights are fixed only in terms of determining the content of these rights ${ }^{2}$. Thus, it is important to consider the protection of certain objects

\footnotetext{
${ }^{1}$ Koval M. (2016). How to protect intellectual property in the field of IT and which of the global trends should be taken into account in Ukrainian legislation. Kharkiv: KHNAMG, 5, p. 2-4.

${ }^{2}$ Drobyazko V. (2009). Legal regulation of copyright and related rights in the European Union. Theory and Practice of Intellectual Property, 1, p. 3-13.
} 
of intellectual property rights in foreign countries.

The existing mechanisms and methods of legal regulation are slower to respond to changes in the rapidly evolving software market. The first legal protection of computer programs was introduced in the United States. In 1980, the Computer Software Copyright Act was passed. For ten years, the example was supported by eight more countries, namely Australia (1984), Japan, Great Britain, France and Germany (1985), Spain (1987), Canada (1988) and China (1990). At the international level, software products are protected by copyright. This is enshrined in the Berne Convention for the Protection of Literary and Artistic Works, in the Treaty of the World Intellectual Property Organization of December 20,1996, in the European Community Directive on the Legal Protection of Computer Programs of May 14, 1991, and in the WTO Agreement on Trade-Related Aspects of Intellectual Property Rights ${ }^{3}$.

Under Article 4 of the World Intellectual Property Organization Copyright Treaty (1996), computer programs are protected as literary works within the meaning of Article 2 of the Berne Convention for the Protection of Literary and Artistic Works. Such protection is applied to computer programs regardless of the method or form of their expression.

It is clear that the approach to the protection of software products as literary works is in itself illogical and does not correspond to the very essence of such products. After all, only the embodiment of the software product in material form is protected, and the content of the product itself is not subject to protection.

The occurrence of legal conflicts in the protection of computer programs indicates that the existing protection of computer programs by copyright is insufficient. Modern computer programs have the characteristics of the object of intellectual property - the invention (the presence of actions or a set of actions, the order of actions in time, the conditions of action, mode) and therefore protected by patent law. According to the European Patent Office, a computer program as such is a kind of tool for implementing a method, a set of instructions and commands for a computer, set out in plain language, and only translated into human language and devoid of essential elements due to the required degree of generalization. It can be transformed into a description of the method as an object of the invention. In the United States today, a patent is granted not only for an invention that contains a computer program and meets the requirements of patentability (novelty, inventive step, industrial applicability), but also for a computer program if it is recorded in a real environment. Such computer programs are patentable and subject to appropriate examination. Special rules for the examination of inventions related to computer programs have been established by the patent offices of Australia, Canada and Japan. In Europe, for the provision of patent protection for computer technology, a patent is issued for an invention made using a computer program (computer technology $)^{4}$.

In addition, the reality is that owners of exclusive intellectual property rights to computer programs, in order to protect their business from the threat of "piracy", widely use license agreements, which transfer the rights to use computer programs. The world's existing free software distribution model is essentially a set of the most common license agreements developed and used by large communities of free software developers. These include the BSD License, the Apache License, the GNU General Public License, and the GNU Lesser General Public License ${ }^{5}$.

The Berkeley Software Distribution License is a software license from the University of Berkeley that contained only four copyright notices with or without copying. First, all copies of the software must contain an indication of the original authors, i.e. the University of Berkeley. Second, each copy or documentation thereof, or any accompanying materials and documents, must contain an indication of all four conditions of distribution. Third, promotional materials indicating the use of licensed software products must contain an additional indication: "This product contains software developed (name of the organization of the original authors)". Fourth, the name of the organization of the original authors or the names of its members may not be used to support or promote the software, unless written consent has been obtained. Because this license allowed the authors of the derivative software to set their own restrictions on use, but established a mandatory written notice when supporting or promoting the derivative software, its use became a complex and bureaucratic process. Therefore, since its creation in the late 1970s, there have been several adaptations of this license. The most common adaptation was FreeBSD. This adapted version of the license currently contains only two terms of free distribution of software products indication of the original authors of the software and inclusion of the license text (information about the owner, license terms and disclaimer) in the software code, documentation and related materials. It should be noted that

\footnotetext{
${ }^{3}$ Gayova T. (2006). Protection of intellectual property rights in the process of creating a startup in the IT industry. Intellectual property in Ukraine: Scientific and practical journal, 9, p. 14-17.

${ }^{4}$ Bilenchuk P. \& Borisova L. (2017). Legal protection of computer programs. Historical - legal journal, 1, p. 82-86.

${ }_{5}^{5}$ Petrenko A. (2016). Copyright in the field of free software. Copyright journal, 2, p. 96-100.
} 
the text of the license indicates the attitude of the FreeBSD project to derivative software products, namely the refusal to present derivative software products and recognition of copyright of each individual primary developer for external presentation and conclusions on FreeBSD programs, documentation and related materials ${ }^{6}$.

Apache License version 2 was created in 2004. The Apache Software Foundation emphasizes the incompatibility with the GPL licenses below version 3. The main license condition of the authors of Apache Software is set out in one sentence: "Applying the terms and conditions of this license, each participant provides you gratuitous, nonrefundable right of reproduction, preparation of derivative works for public use, public performance, transfer under license agreements, as well as distribution of Apache products and derivative works in the form of source code or objective form".

Additional requirements for the free software license include the obligation for users to create and distribute a copy of the license when creating a copy of the product. The process of minor processing must be accompanied by appropriate notes and instructions in the program code. Developers who make their own significant improvements to the program code are allowed to set their own copyright notices and change the license terms of product distribution.

The GNU General Public License applies not only to software products but also to their documentation. More than half of the known samples of free software use this license. It should be noted that under the General Public License, the program and documentation (not code or presentation separately) are fully licensed. Software developers may not impose additional license terms on the program. In the case of modification or revision of the program with the subsequent change of license conditions, such programs or parts of programs must be used (distributed) separately with a separate copy of the license. The new license must also be copyrighted, as changing the terms of the General Public License is prohibited. The GNU Lesser General Public License is a reduced version of the General Public License, which allows the sharing of free and proprietary (paid) software, and therefore indicates the licensing of combined works. This license is most often used by library resources and in its terms is very similar to the Mozilla Public License. When using the Lesser General Public License, the minimum requirements are to provide sufficient information about the set of software libraries used in the combined work, indicating the relevant licenses.

Each copy of the free software must contain not only a reduced version of the license, but also the main document of the General Public License. Summarizing the above characteristics of public licenses, we can state only minor differences concerning the combinations of free and proprietary software, the need to indicate the copyright of primary developers and the inclusion of copies of the basic license to the combined and derivative works. Choosing an open license is both a simple and a difficult task. A large number of factors cause the impact on the end result, as "the most difficult are the decisions on the direction of the software product in the communities of developers and business"7.

In Ukraine, the development of legislative regulation of free software is very poor, so the involvement of foreign experience may be appropriate.

\subsection{European Experience in the Protection of Intellectual Property Rights as a Basis for Improving Ukrainian Legislation}

Ukraine's integration into European and world (international) structures raises the issue of convergence of national and European law. In particular, to participate in the WTO, Ukraine must bring its legislation in line with the Agreement on Trade-Related Aspects of Intellectual Property Rights (TRIPS) 1993, which is one of the main legal documents of this organization ${ }^{8}$.

According to the Partnership and Cooperation Agreement between Ukraine and the EU, signed on 16 July 1994, Ukraine must ensure a level of protection similar to that existing in the Community, including effective means of enforcing such rights. Today, the focus on EU law is becoming a significant factor in the development of legislation in Central and Eastern Europe, the CIS. At the same time, taking into account the dynamics of harmonization of EU intellectual property rights, its specifics, anticipation of a number of issues of the relevant regulation of the World Intellectual Property Organization, in Ukraine EU standards should come to the fore in both improving legislation and assessing the effectiveness of rights 9 .

\footnotetext{
${ }^{6} I d$.

7 Van Lindberg. (2008). Intellectual Property and Open Source: A Practical Guide to Protecting Code. USA: O'REILLY Meda inc., 371p.

${ }^{8}$ Barizah N. (2017). The development of Asian's intellectual property rights law: from TRIPS compliance to harmonization. Indonesia law review, 7 (1), p. 95-112.

${ }^{9}$ Kapitsa Yu. (2005). Directions of adaptation of the legislation of Ukraine in the field of protection of intellectual property to the legislation
} 
Analysis of the harmonization of EU intellectual property rights makes it possible to identify certain stages of formation and development of legal regulation of relations in this area at the EU level. Initially, the conventions on the Community patents and the European patent (1965-1973) were prepared and adopted. Subsequently, directives were adopted to harmonize Member States' trademark law, topography of semiconductor products, and regulations on the application of competition rules to licensing agreements and agreements on the transfer of knowhow, research and development (1984-1989). Subsequently, directives on the harmonization of copyright were adopted; directives on the approximation of laws on biotechnological inventions, industrial designs; creation of EU rights to trademarks and plant varieties; preparation of proposals for harmonization of laws on utility models; adoption of regulations on technology transfer agreements and the fight against piracy (1991-1998). In 1999-2002, a comprehensive Copyright Directive was adopted in the information society; introduction of an EU industrial design and discussion of proposals for the introduction of an EU utility model. At the present stage, the EU pays considerable attention to strengthening the fight against pirated and counterfeit products, as well as intensive work on the introduction of the EU patent. A significant achievement is the adoption of Directive 2004/48 / EU of April 29,2004 on enforcement of intellectual property rights, which is the first act aimed at strengthening the protection of intellectual property rights ${ }^{10}$.

At a certain stage in the development of legal regulation of intellectual property relations in the EU, the gradual harmonization and unification of the legislation of the EU member states on certain issues and objects of intellectual property came to the fore. The differences between these two legal mechanisms can be seen particularly clearly in the example of intellectual property. Harmonization of national rules of law through the issuance of directives only eliminates the most significant differences in the legal systems of member states. The issuance of acts of unification - regulations makes changes to the legal status of various types of results of intellectual activity, because to replace an individual state as a territorial sphere of exclusive rights is a set of territories of member states and the EU as a whole ${ }^{11}$.

Despite the harmonization of national legislation under the Agreement on Trade-Related Aspects of Intellectual Property Rights and other multilateral treaties, there are still significant differences in legislation between Member States, which, on the one hand, prevent intellectual property rights from enjoying an equivalent level of protection throughout the Community, and on the other hand, - focuses on the possibility of applying different forms and methods of realization of intellectual property rights ${ }^{12}$.

This applies to winding-up proceedings related to counterfeiting or piracy (injunctions), interim measures used mainly to provide evidence, to determine the level of damage. In some countries, procedures are used to obtain information and remove counterfeit goods from the market at the expense of the infringer, there is a difference in the application of injunctions to take into account the interests of third parties, elimination of infringing goods and equipment used for piracy, sanctions ${ }^{13}$.

These issues are reflected in the legislative regulation of intellectual property rights in the European Union.

In the Netherlands, there is no decision to confiscate or destroy counterfeit or pirated copyright-related products if the person was not personally involved in the infringement, did not professionally produce and distribute the goods and purchased them solely for personal use.

In the UK, tools used to make pirated copies can only be destroyed if the person who owns them knew or had reason to know that they were intended for such purposes.

In Germany, equipment used exclusively or almost exclusively for the production of pirated copies of copyright objects can be confiscated and destroyed only if they are owned by a pirate, while the relevant rules do not provide for industrial property objects. In the Netherlands, courts have a practice whereby it is possible to oblige an infringer to remove infringing goods from the market with the infringer reimbursing the costs of these measures by compensating customers. Such a practice does not exist in the legislation of the other Member States ${ }^{14}$.

\footnotetext{
of the European Union. Legal journal "Law of Ukraine", 1, p. 58-66.

${ }^{10}$ Ennan R. (2010). Intellectual property law in the legal system of the European Union. European law and comparative jurisprudence. KyivChambori: Logos, 419 p.

${ }^{11} I d$.

${ }^{12}$ Kapitsa Yu. (2005). Protection of intellectual property rights in EU member states. University scientific notes, 3, p. 76-79.

13 Emhart A. (2019). Private law remedies for the infringement of intellectual property rights. Revista chilena de derecho y tecnologia, 8 (2), p. 33-58.

${ }^{14}$ Bocharova N. (2006). EU intellectual property rights. Harmonization with national legislation. [online] Retrieved from: http://veche.kiev.ua/journal/278/.
} 
The legislative work of the EU institutions on the results of intellectual activity is carried out taking into account the constantly progressing international intellectual property law. It should be emphasized that, in contrast to the methods of the World Intellectual Property Organization, the EU has developed a system of directive regulation of the processes of unification and harmonization of intellectual property law ${ }^{15}$. The Court of Justice of the European Union plays a rather important role in the issues of unification and harmonization of legal regulation of relations in the field of protection and use of intellectual property. In the absence of appropriate harmonization of national legislation in the field of intellectual property with the principles of free movement of goods and services and freedom of competition proclaimed by the European Union, the importance of the case law of the Court of Justice of the European Union is difficult to overestimate ${ }^{16}$.

Thus, practice shows that comprehensive unification activities in the field of protection and use of intellectual property are preceded by a stage of practice of law enforcement of a precedent nature, which allows identifying gaps in legal regulation and solving problems ${ }^{17}$.

The place of intellectual property law in the legal system of the EU and European countries is fundamentally different. Thus, in the countries of continental law there are clear features of intellectual property law, which allows distinguishing it into a separate sub-branch of civil law or even a complex independent branch of law. The main purpose of the creation and development of European legislation is to protect the rights and interests of authors, inventors and other creators of intellectual property and other persons who own intellectual property rights. In this case, the institutions of intellectual property rights are allocated for each of the objects (or a homogeneous group of objects) of intellectual property rights and are contained in a separate law governing the legal relationship for the creation and use of a particular object, as well as by laws and court decisions ${ }^{18}$.

Thus, identifying the main ways that can be used to protect intellectual property rights and highlighting them as general provisions that ensure coherence in the protection of infringed intellectual property rights can be considered as one of the goals of further codification in the field of intellectual property and involvement of European experience is a necessary measure for successful integration ${ }^{19}$.

At present, the leading direction in the formation of European Union legislation on intellectual property protection is the formation of European Union rights to certain objects of intellectual property rights, which initiates the formation of the European Union's intellectual property rights as a two-tier institution and acts on security documents of the European Union ${ }^{20}$.

\subsection{Reforming of National Legislation in the Field of Intellectual Property in the System of European Integration Processes}

Significant renewal of mechanisms of legal regulation at the interstate, supranational levels is determined by the search for an effective system of normalization of social relations of different socio-cultural paradigms, leveling national-state borders, which is made possible by phenomena such as regional and global legal integration. "Extrapolation" of such trends causes large-scale changes and reforms in the legal system of Ukraine, which became more relevant with the signing of the Association Agreement between Ukraine and the European Union, the European Atomic Energy Community and their member states in 2014. The European Union, as a unique integration association of the countries of the European continent, creates a new form of law. At the same time, harmonization of legislation is the main legal instrument of integration processes and aims at the coherence of different legal systems of countries, is a necessary component of ensuring the processes of creating a single legal space $^{21}$.

One of the main conditions for Ukraine's integration into the international community as an equal subject is the compliance of its national legislation with generally accepted international requirements and standards. At the present stage, the priority areas for improving domestic legislation in order to harmonize it with international law

\footnotetext{
${ }^{15}$ Rochel J. (2019). Intellectual property and its foundations: Using Art. 7 and 8 to address the legitimacy of the TRIPS. Journal of world intellectual property, 23 (1-2), p. 21-39.

${ }^{16}$ Bihniak O. (2019). Topical issues of protection of intellectual property in the CIS. Revista de derecho civil, 6 (4), p. 171-189.

${ }^{17}$ Ennan R. (2012). Legal protection of intellectual property in the European Union: preconditions of formation, current state, development tendencies. Journal of Civil law, 13, p. 110-118.

${ }^{18} I d$.

${ }^{19}$ Boltanova E. (2019). Principles of intellectual property law as a sub-branch of Russian civil law. Vestnik Tomskogo gosudarstvennogo universiteta, 34, p. 148-159.

${ }^{20}$ Kapitsa Yu. (2005). Protection of intellectual property rights in EU member states. University scientific notes, 3, p. 76-79.

${ }^{21}$ Ovechkina O. (2017). Harmonization of national legislation with the law of the European Union in the field of intellectual property. Pravo.ua, 2, p. 35-39.
} 
are defined at the legislative level and due to Ukraine's desire to join the European Union and the WTO. These priority areas include legislation on the protection of intellectual property ${ }^{22}$.

It should be noted that the problem of protection of intellectual property rights is not unique only for Ukraine, but is common to the whole world. In this sense, it should be noted the ongoing work of the World Intellectual Property Organization (WIPO) to create common platforms for the exchange of such experiences around the world, including European countries, to find the best ways not only to improve legal procedures but also directly protect intellectual property rights. At present, the work of the World Intellectual Property Organization in the field of protection of rights is based on Strategic Goal VI, which was defined during the adoption of the Development Agenda $^{23}$. In line with Strategic Objective VI, ensuring respect for intellectual property on a sustainable basis is a broad concept in which the protection and enforcement of intellectual property rights must take into account the interests of socio-economic development and consumer protection. In this regard, Recommendation 45 of the Development Agenda is the basis for Strategic Goal VI. According to the latter, the protection and enforcement of intellectual property rights should promote technical innovation and the transfer and dissemination of technology to the mutual benefit of producers and users of technical knowledge to promote socio-economic prosperity and balance of rights and responsibilities ${ }^{24}$. The experience of the Advisory Committee on the Protection of Rights, established by the General Assembly of the World Intellectual Property Organization in 2002, is also significant. This Committee has a mandate to provide technical assistance and coordination in the field of protection of rights (however, rulemaking is clearly excluded from this mandate). In accordance with the Recommendations of the Advisory Committee on Rights Protection, it focuses on:

- coordination of activities with public and private organizations in order to combat counterfeiting and piracy;

- public education;

- providing assistance;

- coordination to conduct national and regional training programs for all relevant stakeholders; exchange of information on the protection of rights ${ }^{25}$.

One of the important documents adopted in the framework of approximation of national legislation to the EU legal system was the Partnership and Cooperation Agreement. Chapter VI of this legal act (Articles 49-51) defined one of the priority areas of cooperation in the sphere of intellectual property protection.

Attention to the protection of intellectual property rights in Ukraine has come into play in setting priorities for the country's accession to the WTO. The researchers stressed the imperfection of the level of protection of intellectual property rights, the need to develop the existing legislation and adapt the legal framework for the definition of intellectual property rights to the requirements of the world environment. As a result, since 1999 there has been positive activity in the legal field regarding intellectual property protection ${ }^{26}$.

However, the adaptation of the intellectual property system to transformational conditions is not yet complete. Licensed products in Ukraine have an unacceptably low level in relation to all industrial products - $0.8 \%$ of the total volume of shipped products. This situation in the field of protection of intellectual property is reflected in the obstacles to innovative socio-economic development of the country. Secondly, it negatively affects the formation of the market of intellectual property. Thirdly, it creates a negative image and reputation of Ukraine in the world (for example, as a result of "intellectual piracy" - illegal business activities, the basis of which is the use of copyright and / or related rights, as well as industrial property without an agreement with the owner of these rights by reproduction, distribution, processing, import).

Thus, Ukraine, which has chosen an innovative path of development, faces the urgent task of creating conditions for proper and effective protection of intellectual property rights.

\footnotetext{
${ }^{22}$ Mazurenko S. \& Ennan R. (2006). Legal regulation of intellectual property in the European Union. Actual problems of state and law, 27, p. 378-384.

${ }^{23}$ Aksyutina A., Nestertsova-Sobakar O. \& Tropin V. (2018). Intellectual Property. Dnipro: Dnipropetrovsk State University of Internal Affairs, $138 \mathrm{p}$

${ }^{24}$ Peukert A. (2017). Unification of intellectual property law: structures, actors and aims. Rabels zeitschrift fur auslandisches und internationals privatrecht, 81 (1), p. 158-193.

${ }^{25}$ Orlyuk O. (2016). Protection of intellectual property rights in the context of European integration. Bulletin of the National Academy of Legal Sciences of Ukraine, 3, p. 58-69.

${ }^{26}$ Gavkalova N. (2007). Protection of intellectual property rights as a condition for Ukraine's integration into the world economic system. Culture of the peoples of the Black Sea region, 102, p. 8-11.
} 


\section{Conclusions}

Summing up, we should mention that the level of legislative protection of intellectual property rights is still insufficient. The fragmentation and disunity of the rules governing legal relations in this area do not allow owners to fully exercise their rights.

Legal regulation of the results of creative activity needs to be systematized and further improved taking into consideration the experience of foreign countries, such as, the USA, the EU countries, Australia, Canada and Japan. Special attention should be paid to the international experience of commercialization of intellectual property.

Due to the fact that the main vector of Ukraine's development is integration into the European community, the legal analysis of achievements is especially important, as well as the monitoring of Ukraine's next steps in the process of approximation of Ukrainian legislation to European Union legislation.

Thus, further study of European legal experience in the field of protection of intellectual property rights is important for the adaptation of Ukrainian legislation to the relevant EU legal model. Considering those, we would like to offer, firstly, introduction of obligatory study by the authorities of both the pan-European experience and the experience of individual EU member states in the implementation of programs for the development of support, administration and protection of intellectual activity in the process of drafting relevant regulations. Secondly, it seems reasonable to introduce a system of continuous analysis of decisions made by European countries in the field of intellectual property law, as well as on issues related to general state policy on the administration of intellectual property, in order to implement developed approaches to legislation and law enforcement practice. Thirdly, the creation of a special system of communication with the EU authorities for the purpose of operative consultations in the process of development of new normative acts in the field of intellectual property in Ukraine in order to establish their compliance with European law is necessary.

\section{References}

Aksyutina, A., Nestertsova-Sobakar, O., \& Tropin, V. (2018). Intellectual Property. Dnipro: Dnipropetrovsk State University of Internal Affairs, $138 \mathrm{p}$.

Barizah, N. (2017). The development of Asian's intellectual property rights law: from TRIPS compliance to harmonization. Indonesia law review, 7(1), 95-112. https://doi.org/10.15742/ilrev.v7n1.247

Bihniak, O. (2019). Topical issues of protection of intellectual property in the CIS. Revista de derecho civil, 6(4), 171-189.

Bilenchuk, P., \& Borisova, L. (2017). Legal protection of computer programs. Historical - legal journal, 1, 82-86.

Bocharova, N. (2006). EU intellectual property rights. Harmonization with national legislation. Retrieved from http://veche.kiev.ua/journal/278/

Boltanova, E. (2019). Principles of intellectual property law as a sub-branch of Russian civil law. Vestnik Tomskogo gosudarstvennogo universiteta, 34, 148-159.

Drobyazko, V. (2009). Legal regulation of copyright and related rights in the European Union. Theory and Practice of Intellectual Property, 1, 3-13.

Emhart, A. (2019). Private law remedies for the infringement of intellectual property rights. Revista chilena de derecho y tecnologia, 8(2), 33-58. https://doi.org/10.5354/0719-2584.2019.53985

Ennan, R. (2010). Intellectual property law in the legal system of the European Union. European law and comparative jurisprudence. Kyiv-Chambori: Logos, $419 \mathrm{p}$.

Ennan, R. (2012). Legal protection of intellectual property in the European Union: preconditions of formation, current state, development tendencies. Journal of Civil law, 13, 110-118.

Gavkalova, N. (2007). Protection of intellectual property rights as a condition for Ukraine's integration into the world economic system. Culture of the peoples of the Black Sea region, 102, 8-11.

Gayova, T. (2006). Protection of intellectual property rights in the process of creating a startup in the IT industry. Intellectual property in Ukraine: Scientific and practical journal, 9, 14-17.

Kapitsa, Yu. (2005a). Directions of adaptation of the legislation of Ukraine in the field of protection of intellectual property to the legislation of the European Union. Legal journal "Law of Ukraine", 1, 58-66.

Kapitsa, Yu. (2005b). Protection of intellectual property rights in EU member states. University scientific notes, 3, 76-79.

Koval, M. (2016). How to protect intellectual property in the field of IT and which of the global trends should be 
taken into account in Ukrainian legislation. Kharkiv: KHNAMG, 5, p. 2-4.

Mazurenko, S., \& Ennan, R. (2006). Legal regulation of intellectual property in the European Union. Actual problems of state and law, 27, 378-384.

Orlyuk, O. (2016). Protection of intellectual property rights in the context of European integration. Bulletin of the National Academy of Legal Sciences of Ukraine, 3, p. 58-69.

Ovechkina, O. (2017). Harmonization of national legislation with the law of the European Union in the field of intellectual property. Pravo.ua, 2, p. 35-39.

Petrenko, A. (2016). Copyright in the field of free software. Copyright journal, 2, 96-100.

Peukert, A. (2017). Unification of intellectual property law: structures, actors and aims. Rabels zeitschrift fur $\begin{array}{lllll}\text { auslandisches und internationals } & \text { privatrecht, } & \text { 81(1), }\end{array}$ https://doi.org/10.1628/003372516X14817241955079

Rochel, J. (2019). Intellectual property and its foundations: Using Art. 7 and 8 to address the legitimacy of the TRIPS. Journal of world intellectual property, 23(1-2), 21-39. https://doi.org/10.1111/jwip.12138

Van, L. (2008). Intellectual Property and Open Source: A Practical Guide to Protecting Code. USA: O’REILLY Meda inc., $371 \mathrm{p}$.

\section{Copyrights}

Copyright for this article is retained by the author(s), with first publication rights granted to the journal.

This is an open-access article distributed under the terms and conditions of the Creative Commons Attribution license (http://creativecommons.org/licenses/by/4.0/). 